\title{
The effect of temperature and shearing rate on dynamic viscosity of RME containing fuels
}

\begin{abstract}
The paper presents the results of a research on determining the temperature and shearing rate effect on dynamic viscosity of type B biofuels. This type of fuels are diesel fuels containing a biocomponent supplement. The "B" value denotes a volumetric share of the biocomponent in a mixture with diesel fuel. Three kinds of biofuels have been tested: B100 (100\% RME), B20 (20\% RME) and B5 (5\%RME). B20 and B5 biofuels were prepared on the basis of commercial $V E R V A$ ON diesel oil. The dynamic viscosity of B100 RME biofuels within the temperature range from 30 to $-15^{\circ} \mathrm{C}$ assumes values from c.a. 10 to $95 \mathrm{mPa}$. The dynamic viscosity of RME biofuels at constant temperature $25^{\circ} \mathrm{C}$ within the range of shearing rate from 0 to $2000 \mathrm{~s}^{-1}$ changed its value from 7 to $15 \mathrm{mPa} \cdot \mathrm{s}$. B5 biofuel reveals also a strong dependency of the dynamic viscosity in the shearing rate function. For the lowest values of the shearing forces the dynamic viscosity assumed the values of $2.5 \mathrm{mPa}$. The dynamic viscosity grew reaching the value of $8.5 \mathrm{mPa} \cdot \mathrm{s}$ at $2000 \mathrm{~s}^{-1}$ along with the increasing shearing forces. The research demonstrated that the dynamic viscosity of fuels is seriously affected not only by the temperature, as has been hitherto suggested, but also by the shearing rate.
\end{abstract}

Key words: biodiesel, biofuels type B, RME, dynamic viscosity, shearing rate

\section{Wpływ temperatury i szybkości ścinania na lepkość dynamiczną paliw zawierających RME}

\begin{abstract}
W artykule przedstawiono wyniki badań dotyczacych określenia wptywu temperatury oraz szybkości ścinania na lepkość dynamiczna biopaliw typu B. Paliwami tego typu sq oleje napędowe zawierajace dodatek biokomponentu. Wartość przy literze „B” oznacza udziat objętościowy biokomponentu w mieszaninie z olejem napędowym. Badaniom poddano trzy rodzaje biopaliw: B100 (100\% RME), B20 (20\% RME) i B5 (5\% RME). Biopaliwa B20 i B5 skomponowano w oparciu o handlowy olej napędowy VERVA ON. Lepkość dynamiczna biopaliwa B100 RME w zakresie temperatur od 30 do $-15^{\circ} \mathrm{C}$ przyjmuje wartości od ok. 10 do $9 \mathrm{mPa}$. Lepkość dynamiczna biopaliwa RME przy stałej temperaturze wynoszacej $25^{\circ} \mathrm{C}$ w zakresie szybkości ścinania od 0 do $2000 \mathrm{~s}^{-1}$ zmieniała swoja wartość od 7 do $15 \mathrm{mPa}$.s. Biopaliwo B5 wykazuje również silna zależność lepkości dynamicznej w funkcji szybkości ścinania. Dla najniższych wartości sit ścinajacych lepkość dynamiczna przyjmowała wartość 2,5 mPa·s. Wraz ze wzrostem sit ścinających rosła również lepkość dynamiczna osiagając przy $2000 \mathrm{~s}^{-1}$ wartość 8,5 mPa.s. Przeprowadzone badania pokazaty, że na lepkość dynamiczna paliw duży wplyw wywiera nie tylko temperatura jak dotychczas sądzono, ale również szybkość ścinania.
\end{abstract}

Słowa kluczowe: biodiesel, biopaliwo typu B, RME, lepkość dynamiczna, szybkość ścinania

\section{Introduction}

Two of the basic parameters determining the biofuel usefulness for diesel engines are its viscosity and density. From the above mentioned parameters, both kinematic and dynamic viscosity are characterized by a relatively large amplitude of parameter changes in the temperature function.

Quality standards PN-EN 590:2006 for diesel fuel and EN ISO3104 for FAME fuel determine only the kinematic viscosity. No obligatory norm has been introduced so far for determining the dynamic viscosity. Kinematic viscosity is a parameter describing the resistance of fluid flow due to gravity forces. In order to determine the kinematic viscosity the flow time for constant fluid volume through a capillary tube of a standard viscosimeter under the influence of gravity forces is measured, under repeatable conditions and at known and strictly controlled temperature. The value of the kinematic viscosity is computed by multiplying the flow time by viscosimeter standardization constant.

The analysis of the subject literature shows a variety of values of RME kinematic viscosity, which according to some authors at the temperature of e.g. $20^{\circ} \mathrm{C}$ ranged from

\section{Wstęp}

Podstawowymi parametrami decydującymi o przydatności szczególnie biopaliw do zasilania silników z zapłonem samoczynnym są lepkość i gęstość. Stosunkowo dużą amplitudą zmian wartości parametru w funkcji temperatury charakteryzuje się lepkość zarówno kinematyczna, jak i dynamiczna.

Normy jakościowe PN-EN 590:2006 dotyczące oleju napędowego oraz EN ISO 3104 na FAME określają tylko lepkość kinematyczną. Dotychczas nie wprowadzono normy obligatoryjnej na bezpośrednie wyznaczanie lepkości dynamicznej. Lepkość kinematyczna jest to parametr określający opór przepływu, na jaki napotyka ciecz pod wpływem sił grawitacyjnych. W celu określenia lepkości kinematycznej mierzy się czas przepływu stałej objętości cieczy, pod wpływem sił grawitacyjnych, przez kapilarę wzorcowanego lepkościomierza, w powtarzalnych warunkach, w znanej i ściśle kontrolowanej temperaturze. Wartość lepkości kinematycznej oblicza się, mnożąc zmierzony czas przepływu przez stałą wzorcowania lepkościomierza, przy czym norma dopuszcza trzy grupy lepkościomierzy w zależności od ro- 
6 [3] to $2000 \mathrm{mPa} \cdot \mathrm{s}$ [4]. However, it seems that the scatter of results was not as wide and was rather due to a measurement error or an application of methods of little accuracy. Therefore, even a small mistake during measurement may cause a considerable scatter of the obtained kinematic viscosity values. Additionally such an error may be multiplied while the dynamic viscosity is determined.

In recent years a rapid development of injection systems based on pump-injectors or common rail has been observed, where very high pressure occurs. In this situation it is extremely important to determine the fluid flow resistance under dynamic, not static conditions. It is particularly important when type "B" fuels with biocomponent supplement of higher viscosity are used for Diesel engine fueling. Therefore the dynamic, not kinematic viscosity should be determined. So far, the dynamic viscosity has not been determined separately, but indirectly derived from the kinematic viscosity. It was due to a lack of proper tools which were relatively expensive. However, a dynamic development of rheometers in recent years, particularly dynamic types, allowed for most accurate determination of the dynamic viscosity. Moreover, for a better assessment of fuel mechanical properties the influence of many rheological parameters on the behavior of fuels or biofuels may also be tested.

The advantages of the use of the rotary rheometers for viscosity determination comprise: small volume of fuel sample (about $50 \mathrm{~cm}^{3}$ is enough), full automatic and computerized measurements, the possibility of testing both viscous and elastic properties, possible investigation of the tixotropy and antitixotropy phenomena.

The dynamic viscosity is a measure of fluid's resistance to flow or fluid deformation - Polish standard PN-EN ISO 3104. Viscosity is responsible for flow resistance through the fuel supply system elements such as fuel lines and fuel filters [5]. It also affects the injection course, stream range and fuel spraying in the engine combustion chamber. It influences the lubrication properties, which is particularly important in the case of rotary injection pumps because in the pumps of this type the pump elements are lubricated with diesel oil. It influences the functioning of the newest generation of injection systems based on common rail or injection pump to a higher extent than others. High shearing rates occurring on the elements cutting off the fuel flow or changing the flow direction cause additional and considerable increase in the dynamic viscosity, which in case a biocomponent supplement with viscosity higher than diesel fuel is used, may affect the proper functioning of the fuel supply and fuel injection systems [7]. There is also a strict relationship between the viscosity, the temperature and the shearing rate [7].

There is a serious problem concerning an excessive viscosity of some biofuels, which in recent years has become one of the key issues. It is primarily connected with the use of injection systems, which supply the fuel to the engine at dynamic pressure reaching $260 \mathrm{MPa}$. Therefore, even a slight increase in this parameter may negatively affect the work of injection system. The fact that biofuels would enter the fuel market was known since 1997, because during the World dzaju i zakresu lepkości badanej cieczy, dlatego metodyka pomiaru różni się od podanej wyżej.

Jak wynika z analizy literatury tematu, wartość lepkości kinematycznej RME, według różnych autorów, w temperaturze np. $20^{\circ} \mathrm{C}$, zawiera się w przedziale od 6 [3] do 2000 $\mathrm{mPa} \cdot \mathrm{s}$ [4]. Wydaje się jednak, że tak dużego rozrzutu nie ma, a uzyskane wyniki były, niestety, efektem błędu pomiaru lub zastosowania mało precyzyjnej metodyki. Dlatego popełnienie nawet małego błędu w trakcie pomiarów może powodować duży rozrzut uzyskanej wartości lepkości kinematycznej. Dodatkowo, taki błąd może być zwielokrotniony przy wyznaczeniu lepkości dynamicznej.

W ostatnich latach obserwuje się gwałtowny rozwój aparatury wtryskowej, bazującej na systemach pompowtryskiwaczy lub układzie common rail, gdzie mamy do czynienia z bardzo wysokimi ciśnieniami. W takiej sytuacji bardzo istotne jest określanie oporu przepływu płynu w warunkach dynamicznych, a nie - statycznych. Jest to o tyle ważne, że do zasilania silników ZS można stosować paliwa typu B z dodatkiem biokomponentów, których, jak wiemy, lepkość jest wyższa. Dlatego powinno się wyznaczać precyzyjnie lepkość dynamiczną, a nie kinematyczną. Dotychczas nie wyznaczano lepkości dynamicznej, a tylko ją wyliczano z kinematycznej, ponieważ nie było odpowiednich narzędzi lub były stosunkowo drogie. Jednak w ostatnich latach obserwujemy bardzo dynamiczny rozwój reometrów, szczególnie rotacyjnych, które bardzo precyzyjnie potrafią wyznaczać lepkość dynamiczną. Dodatkowo, dla lepszej oceny właściwości mechanicznych paliw można wyznaczać wpływ wielu parametrów reologicznych na zachowanie się paliwa czy biopaliwa.

Do zalet stosowania reometrów rotacyjnych do wyznaczenia lepkości należą: mała objętość potrzebnej próbki paliwa (wystarczy około $50 \mathrm{~cm}^{3}$ ), pełna automatyzacja i komputeryzacja pomiarów, możliwość badania cech lepkich i sprężystych, możliwość badania zjawisk tiksotropii i antytiksotropii.

Lepkość dynamiczna jest miarą oporu przepływu lub deformacji cieczy - Polska norma PN-EN ISO 3104. Lepkość odpowiada za opór przepływu paliwa przez elementy układu zasilania, jak przewody oraz filtry paliwowe [5]. Wpływa na przebieg wtrysku, zasięg strugi i rozpylanie paliwa w komorze spalania silnika. Wpływa również na właściwości smarne, co jest szczególnie ważne w przypadku rotacyjnych pomp wtryskowych, ponieważ w tego typu pompach smarowanie elementów pompy odbywa się olejem napędowym. Jeszcze większy wpływ wywiera na poprawność pracy najnowszej generacji układów wtryskowych, bazujących na systemie common rail lub pompowtryskiwaczach. Na elementach odcinających chwilowy dopływ paliwa lub zmieniających kierunek przepływu występują duże prędkości ścinania, co powoduje dodatkowe, znaczne zwiększenie lepkości dynamicznej, dlatego w przypadku zastosowania dodatku biokomponentu, który cechuje się większą lepkością od oleju napędowego, może wpłynąć na poprawność pracy układów zasilania i wtrysku paliwa [7]. Istnieje również ścisła zależność między lepkością a temperaturą i prędkością ścinania [7]. 
Climate Summit in Kyoto it was agreed that one of the ways to reduce $\mathrm{CO}_{2}$ emission by vehicles would be a progressive replacement of the conventional crude oil derivative fuels with biofuels. Therefore, the manufacturers should adjust the injection systems also for the fuels with a 20 to $40 \%$ higher viscosity. Biodiesel quality also poses a problem. It turns out that FAME usually contains more products of incomplete conversion to esters of oil obtained through the transesterification process. EN-14214 standard for FAME Biodiesel fuel states the maximum admissible amount of monoacyloglycerols in fuels is $0.8 \%$, whereas diacylglyceryl ethers - only $0.2 \%(\mathrm{~m} / \mathrm{m})$. Another problem is a wrong separation of ester from glycerine phase, since even trace amounts of glycerine phase left over lead to a considerable increase in viscosity. As results from the Author's own research, viscosity of properly separated glycerine phase obtained after rapeseed oil methanolysis at $20^{\circ} \mathrm{C}$ is approximately $940 \mathrm{mPa} \cdot \mathrm{s}$, whereas in diesel fuel it is approximately $8 \mathrm{mPa} \cdot \mathrm{s}, \mathrm{RME}$ esters approximately $13 \mathrm{mPa} \cdot \mathrm{s}$, whereas rapeseed oil approximately $70 \mathrm{mPa} \cdot \mathrm{s}$. It results from the data given above that at $20^{\circ} \mathrm{C}$ the oil viscosity is 5.5 times higher and the viscosity of glycerin phase by over 72 times higher than the RME viscosity [7].

\section{Methods of research}

The measuring set with two coaxial cylinders was applied in the rheometer. Beside the cone/plate viscometer it is one of the most accurate devices for the measurement of the dynamic viscosity of fuels and biofuels. Figure 1 shows the schematic diagram of the measuring set with marked parameters which served to formulate the main relationships: tangent force, torsion moment, shearing force and dynamic viscosity.

Assuming that the tested sample has the height $\mathrm{H}$, the tangent force in the fluid at distance $r$ from the rotation axis may be expressed by formula 1. Considering rotating frequency of the spinning element and the outer diameter of the spinning element $\mathrm{R}_{1}$ and the inner diameter of the cylinder sleeve $\mathrm{R}_{2}$ filled with the tested fluid, we may derive formula 2 describing the relationship for the shearing force. If the torsion moment caused by the tangent force is equal it may be generally written as $\mathrm{M}=$ F.r. On the other hand for the set applied in the rheometer, i.e. the measuring set with coaxial cylinders, the torsion moment may be shown by formula 3 . The tangent friction forces transferred by the fluid to the inner cylinder cause the described torsion moment $\mathrm{M}$. Considering the above mentioned assumptions the formula for the dynamic viscosity using a coaxial cylinder set may be described using formula 4 .

$$
\begin{gathered}
\mathrm{F}_{\gamma}=2 \pi \mathrm{rH} \tau_{\gamma} \\
\dot{\gamma}=\frac{2 \Omega}{1-\frac{\mathrm{R}_{1}^{2}}{\mathrm{R}_{2}^{2}}} \\
\mathrm{M}=\frac{4 \pi \eta \mathrm{H} \Omega}{\frac{1}{\mathrm{R}_{1}^{2}}-\frac{1}{\mathrm{R}_{2}^{2}}} \\
\eta=\frac{1}{4 \pi \mathrm{H}}\left(\frac{1}{\mathrm{R}_{1}^{2}}-\frac{1}{\mathrm{R}_{2}^{2}}\right) \frac{\mathrm{M}}{\Omega}
\end{gathered}
$$

Problem z nadmierną lepkością niektórych biopaliw jest bardzo poważny, a w ostatnich latach urósł do rangi jednego z kluczowych. Wiąże się to przede wszystkim ze stosowaniem aparatury wtryskowej, która podaje paliwo do silnika przy ciśnieniu dynamicznym dochodzącym do 260 $\mathrm{MPa}$. Dlatego, nawet niewielkie zwiększenie wartości tego parametru, może negatywnie wpłynąć na pracę aparatury wtryskowej. O tym, że biopaliwa będą wchodziły na rynki paliwowe było wiadomo już od 1997 r., ponieważ podczas Światowej Konferencji Klimatycznej w Kioto ustalono, że jednym ze sposobów ograniczenia przez motoryzację emisji $\mathrm{CO}_{2}$ będzie stopniowe zastępowanie konwencjonalnych ropopochodnych paliw biopaliwami. Dlatego producenci powinni dostosować układy wtryskowe również do paliw o większej lepkości od 20 do 40\%. Pewnym problemem jest też jakość biodiesla. Okazuje się, że często w FAME mamy więcej produktów niecałkowitej konwersji oleju w estry, uzyskiwanego w procesie transestryfikacji. Norma EN 14214 dotycząca biopaliwa typu biodiesel FAME podaje, że monoacylogliceroli może być w paliwie maksymalnie $0,8 \%$ $(\mathrm{m} / \mathrm{m})$, natomiast diacylogliceroli - tylko $0,2 \%(\mathrm{~m} / \mathrm{m})$. Problemem jest też złe oddzielenie fazy estrowej od glicerynowej. Tymczasem pozostawienie nawet śladowych ilości fazy glicerynowej powoduje znaczny wzrost lepkości. Jak wynika z badań własnych autora artykułu, lepkość prawidłowo oddzielonej fazy glicerynowej, uzyskanej po metanolizie oleju rzepakowego w temperaturze $20^{\circ} \mathrm{C}$ wynosi około $940 \mathrm{mPa} \cdot \mathrm{s}$, podczas gdy oleju napędowego ok. $8 \mathrm{mPa} \cdot \mathrm{s}$, estrów RME około $13 \mathrm{mPa} \cdot \mathrm{s}$, natomiast oleju rzepakowego ok. $70 \mathrm{mPa} \cdot \mathrm{s}$. Z powyższego wynika, że w temperaturze $20^{\circ} \mathrm{C}$ lepkość oleju rzepakowego jest o 5,5-krotnie większa, a fazy glicerynowej o ponad 72 razy większa od lepkości RME [7].

\section{Metodyka badań}

W reometrze zastosowano układ pomiarowy o dwóch cylindrach współosiowych. Jest to jednocześnie, obok układu stożek-płytka, jeden z dwóch najbardziej precyzyjnych

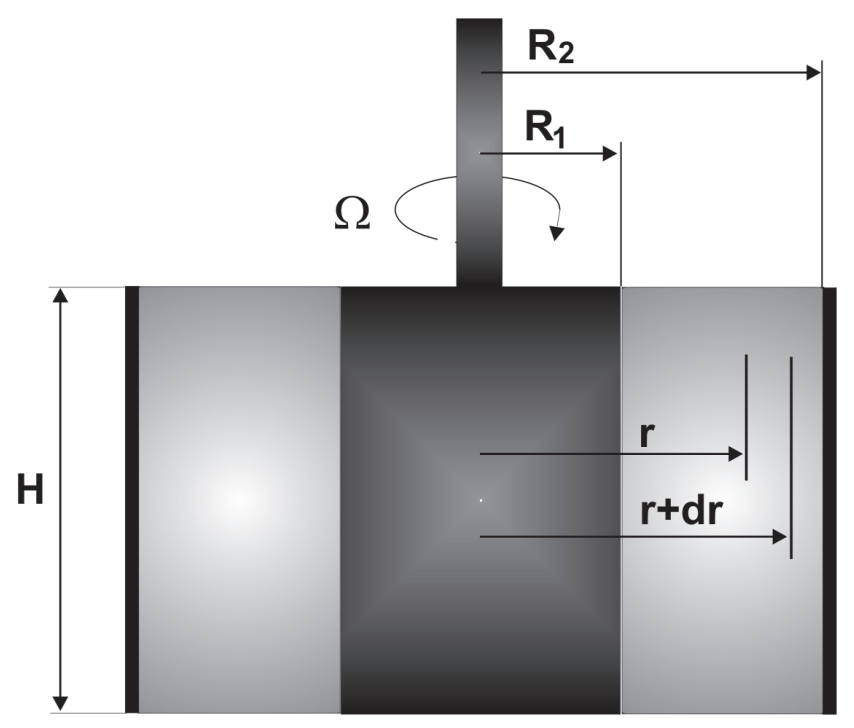

Fig. 1. Measuring set with coaxial cylinders Rys. 1. Układ pomiarowy o cylindrach współosiowych 
where: $\Omega$ - rotating frequency of the spinning element, $\mathrm{M}$ - torsion moment acting on the spinning element axis, $\mathrm{H}$ - height of the biofuel sample, $\mathrm{r}$ - distance from the axis of rotation, $\mathrm{R}_{1}$ - outer radius, $\mathrm{R}_{2}-$ inner radius of cylinder sleeve.

\section{Aim and scope of research}

The research aimed at determining the effect of the temperature and the shearing rate on the dynamic viscosity of type B biofuels. Three kinds of fuels were prepared: $\mathrm{B} 5, \mathrm{~B} 20$ and B100. The value beside "B" denotes a volumetric proportion of RME in the mixture with the diesel oil. These biofuel types were selected because, the recently passed act on biocomponents and biofuels allows to use up to $5 \%$ of biocomponent supplements in the fuels without the obligatory relevant information for the buyer about the supplement. The second chosen biofuel was B20 since by 2020 an average biocomponent share in the total balance of fuels consumed by the transport will reach at least $20 \%$. Hence, the research will show how much the viscosity of the fuels with $20 \%$ RME supplement will grow. The third biofuel selected for comapartive testing was B100, i.e. pure RME ester. The basic fuel for type B20 and B5 biofuels was the commercial VERVA ON diesel oil manufactured by PKN ORLEN S.A. The research determined the variability of the dynamic viscosity within the temperature range from -15 to $30^{\circ} \mathrm{C}$. Such a range of temperatures was assumed because due to the applied thermostatic bath it was impossible to lower the sample temperature below $-15^{\circ} \mathrm{C}$. On the other hand rising the upper temperature above $30^{\circ} \mathrm{C}$ was considered unnecessary because it does not generally affect the change of the dynamic viscosity. In the initial part of the test the shearing rate of the rheometer spindle was constant 1050 $\mathrm{s}^{-1}$. Subsequently, the influence of variable shearing rates on the dynamic viscosity was determined for the same biofuels. The range of the shearing rate changes was very wide - from 0 to $2000 \mathrm{~s}^{-1}$.

\section{Characteristics of the test stand}

The main device used at the test stand was ReolabQC rheometer manufactured by a German company - Anton Paar GmbH (Fig. 2). The rheometer is a devise designed for determining mechanical and rheological parameters of fluids and fuels. The device measures among other things, the dynamic viscosity, surface tension, shearing forces, shearing rate, shearing tension, etc. The rheometer is also equipped with a temperature sensor and an integrated system of time measurement. In order to determine the effect of temperature on the above mentioned parameters, the rheometer used at the measuring stand was additionally equipped with a thermostatic bath. The results of research using the measuring system of the viscosimeter were sent to a computer and saved there to be subsequently processed using RHEOPLUS/32 V3.0.

The rheometer was equipped with an internal memory and the system for research program generation. Figure 3 presents the algorithm of the ReolabQC rheometer external układów do pomiaru lepkości dynamicznej paliw i biopaliw. Na rysunku 1 przedstawiono schemat układu pomiarowego z zaznaczeniem parametrów, za pomocą których wyprowadzono główne zależności na: siłę styczną, moment skręcający, siłę ścinającą oraz lepkość dynamiczną.

Gdy przyjmiemy, że rozważana próbka ma wysokość H, to siła styczna w płynie w odległości r od osi obrotów może być wyrażona wzorem (1). Uwzględniając częstość obrotową wirującego elementu oraz średnicę zewnętrzną elementu wirującego $R_{1}$ i średnicę wewnętrzną tulei $R_{2}$, wypełnionej płynem badanym, możemy wyprowadzić zapisaną wzorem (2) zależność na siłę ścinającą. Moment skręcający, wywoływany siłą styczną, możemy zapisać ogólnie $\mathrm{M}=\mathrm{F} \cdot \mathrm{r}$. Natomiast dla układu zastosowanego w reometrze, czyli układu pomiarowego o cylindrach współosiowych, moment skręcający może być wyrażony wzorem (3). Siły tarcia stycznego przenoszone przez płyn na cylinder wewnętrzny powodują powstawanie opisanego momentu skręcającego M. Uwzględniając powyższe założenia, możemy zapisać wzorem (4) zależność na lepkość dynamiczną przy zastosowaniu układu pomiarowego o cylindrach współosiowych,

gdzie: $\Omega$ - częstość obrotowa wirującego elementu, $\mathrm{M}-$ moment skręcający, działający na osi wirującego elementu, $\mathrm{H}$ - wysokość próbki biopaliwa, $\mathrm{r}$ - odległość od osi obrotu, $\mathrm{R}_{1}$ - promień zewnętrzny wrzeciona reometru, $\mathrm{R}_{2}$ - promień wewnętrzny tulei cylindra.

\section{Cel i zakres badań}

Celem badań było określenie wpływu temperatury oraz szybkości ścinania na lepkość dynamiczną biopaliw typu B. Skomponowano trzy rodzaje paliw: B5, B20 i B100. Wartość przy literze B oznacza udział objętościowy RME w mieszaninie z olejem napędowym. Wybrano tego typu biopaliwa, ponieważ obecnie można zgodnie z obowiązującą ustawą o biokomponentach i biopaliwach stosować do 5\% dodatku biokomponentu, bez dodatkowego informowania kupującego, że olej napędowy posiada domieszkę biokomponentu. Drugim biopaliwem było B20, ponieważ docelowo do $2020 \mathrm{r}$. średni udział biokomponentu w całkowitym bilansie paliw konsumowanych w transporcie ma wynieść co najmniej 20\%. Badania zatem pokażą o ile wzrośnie lepkość paliwa, zawierającego dodatek 20\% RME. Trzecim biopaliwem dla porównania było B100, czyli czysty ester RME. Paliwem bazowym dla biopaliw typu B20 i B5 był handlowy olej napędowy VERVA ON, wyprodukowany w koncernie PKN ORLEN S.A. W trakcie badań wyznaczono zmienność lepkości dynamicznej w zakresie temperatur od -15 do $30^{\circ} \mathrm{C}$. Przyjęto taki zakres temperaturowy, ponieważ ze względu na zastosowaną wannę termostatyczną nie można było obniżyć temp. próbek poniżej $-15^{\circ} \mathrm{C}$. Natomiast uznano, że górnej wartości nie ma potrzeby podnosić powyżej $30^{\circ} \mathrm{C}$, gdyż podwyższenie temperatury nie wpływa zasadniczo na zmianę lepkości dynamicznej. W pierwszej części badań szybkość ścinania wrzeciona reometru była stała i wynosiła $1050 \mathrm{~s}^{-1}$. Następnie dla tych samych biopaliw B określono, jaki wpływ na lepkość dynamiczną wywiera zmienna szybkość ścinania. Zakres zmian szybkość ścinania był bardzo duży i wynosił od 0 do $2000 \mathrm{~s}^{-1}$. 
control. The rheometer may be externally controlled by a computer which allows the creation and editing of the measuring programs, which makes optional and multiple parameter setting and saving possible without the necessity of deleting.

\section{Results and discussion}

Figures $4 \mathrm{~b}$ through $6 \mathrm{~b}$ show the results of the research on determining the effect of the temperature and the shearing rate on the dynamic viscosity.

Figure 4 a shows the diagram of B100 fuel (100\% RME) dynamic viscosity changes in the function of temperature. Within the range of temperatures from 30 to $-15^{\circ} \mathrm{C}$ the dynamic viscosity changed its value from c.a. 10 to $95 \mathrm{mPa} \cdot \mathrm{s}$. Three characteristic sections may be distinguished on the analyzed diagram. Within the temperature range from 30 to c.a. $15^{\circ} \mathrm{C}$ the dynamic viscosity remained practically unchanged. With temperature decreasing from c.a. $15^{\circ} \mathrm{C}$ to $-3^{\circ} \mathrm{C}$ a marked increase in the dynamic viscosity may be observed. When the temperature is further decreased from $-3^{\circ} \mathrm{C}$ to $-15^{\circ} \mathrm{C}$ a considerable increase in the dynamic viscosity is recorded. At $-5^{\circ} \mathrm{C}$ the dynamic viscosity is c.a. 20 $\mathrm{mPa} \cdot \mathrm{s}$, whereas at $-15^{\circ} \mathrm{C}$ the viscosity increases over four times and reaches $96 \mathrm{mPa} \cdot \mathrm{s}$.

Figure $4 \mathrm{a}$ shows the effect of the shearing force on the dynamic viscosity of B100RME biofuel. The tests were conducted for a constant temperature of $25^{\circ} \mathrm{C}$. As may be seen in the figure the dynamic viscosity at the same temperature changes its values from 7 to $15 \mathrm{mPa} \cdot \mathrm{s}$. It confirms the fact that at large increases in the shearing rate the value of the dynamic viscosity grows considerably (as much as twice). This information is particularly important for fueling of the new generation engines, as is in the case of pump injection or common rail systems, where very high pressure of injection occurs and the fuel dose is divided into several smaller ones. In such systems we observe considerable increases in the shearing rate, therefore the dynamic viscosity, irrespectively of the temperature may grow considerably causing an additional growth of the fuel flow resistance.

Research results presented in Figures 5a and 6a show the character of dynamic viscosity changes, respectively in biofuels B20 and B5 (5 and 20\% RME). For the B20 biofuel at $30^{\circ} \mathrm{C}$ the viscosity was $6.5 \mathrm{mPa} \cdot \mathrm{s}$, but reached the value of $1.2 \mathrm{mPa} \cdot \mathrm{s}$ when the temperature fell to $-15^{\circ} \mathrm{C}$. The viscosity value of $6.3 \mathrm{mPa} \cdot \mathrm{s}$ was obtained for $\mathrm{B} 5$ biofuel at $30^{\circ} \mathrm{C}$, but it grew when the fuel sample cooled and reached $9.7 \mathrm{mPa} \cdot \mathrm{s}$ at $-15^{\circ} \mathrm{C}$.

Figures $5 \mathrm{~b}$ and $6 \mathrm{~b}$ show the influence of the shearing forces on the dynamic viscosity. Figure $4 \mathrm{~b}$ illustrates the character of the changes for B20 biofuel. At the shearing forces close to zero, the dynamic viscosity was $3.5 \mathrm{mPa} \cdot \mathrm{s}$. The viscosity grew with the increase of the shearing rate and at the maximum value of this parameter $\left(2000 \mathrm{~s}^{-1}\right)$ reached $10 \mathrm{mPa} \cdot \mathrm{s}$. As may be seen, due to the temperature the value of the dynamic viscosity may grow up to three times. Figure $5 \mathrm{~b}$ shows how the dynamic viscosity of B5 fuel changes in the function of the shearing rate. For the lowest values of this parameter the dynamic viscosity assumed the value of 2.5

\section{Charakterystyka stanowiska badawczego}

Głównym urządzeniem stanowiska badawczego był reometr ReolabQC niemieckiej firmy Anton Paar GmbH (rys. 2). Wymieniony reometr jest przyrządem przeznaczonym do wyznaczania parametrów mechanicznych, reologicznych płynów oraz paliw. Przyrząd mierzy m.in. lepkość dynamiczną, napięcie powierzchniowe, siły ścinające, szybkość ścinania, napięcie ścinania itp. Reometr jest również wyposażony w czujnik temperatury oraz zintegrowany system pomiaru czasu. W celu określenia wpływu temperatury na wymienione parametry stanowisko badawcze, czyli reometr, został dodatkowo wyposażony w wannę termostatyczną. Wyniki badań poprzez system pomiarowy lepkościomierza były przesyłane do komputera i tam zapisywane oraz obrabiane w programie RHEOPLUS/32 V3.0.

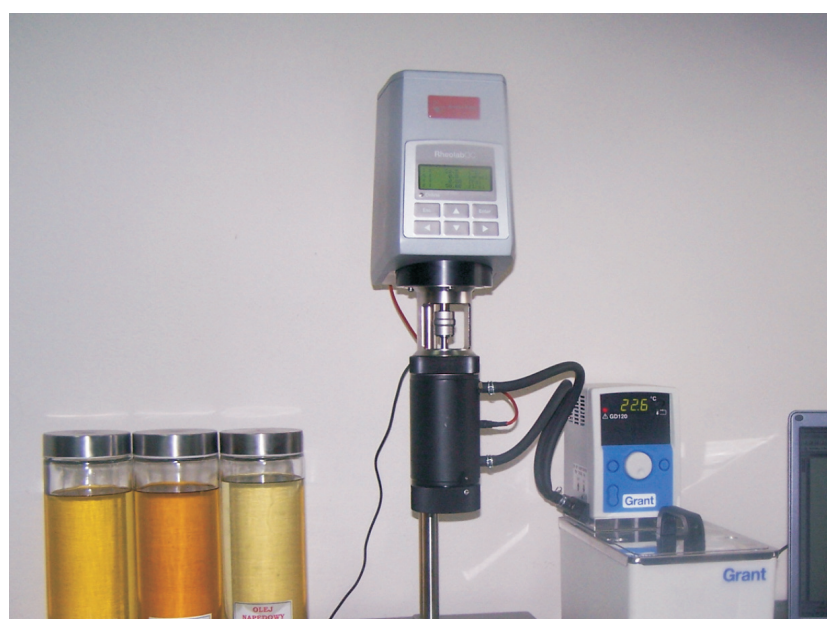

Fig. 2. The test stand with a rheometer and thermostatic bath Rys. 2. Stanowisko badawcze wyposażone $w$ reometr oraz wanne termostatyczna

Reometr wyposażony jest w wewnętrzną pamięć oraz system generowania programów badań. Na rysunku 3 przedstawiono algorytm sterowania reometrem ReolabQC. Pracą reometru z zewnątrz może zarządzać komputer umożliwiający tworzenie i edytowanie programów pomiarowych, dzięki któremu możliwe jest dowolne i wielokrotne ustawienie parametrów i zapisanie ich bez konieczności kasowania.

\section{Wyniki badań i dyskusja}

Na rysunkach 4b-6b przedstawiono wyniki badań określających wpływ temperatury oraz szybkości ścinania na lepkość dynamiczną.

$\mathrm{Na}$ rysunku 4a przedstawiono wykres zmian lepkości dynamicznej biopaliwa B100 (100\% RME) w funkcji temperatury. $\mathrm{W}$ zakresie temperatur od 30 do $-15^{\circ} \mathrm{C}$ lepkość dynamiczna zmieniała swoją wartość od ok. 10 do $95 \mathrm{mPa} \cdot \mathrm{s}$. W analizowanym wykresie można wyróżnić trzy odcinki charakterystyczne. W zakresie temperatur od 30 do ok. $15^{\circ} \mathrm{C}$ lepkość dynamiczna praktycznie nie ulega zmianom. Wraz $\mathrm{z}$ obniżaniem temperatury od ok. $15^{\circ} \mathrm{C}$ do $-3^{\circ} \mathrm{C}$ obserwuje się stopniowy wzrost lepkości dynamicznej. Obniżając 


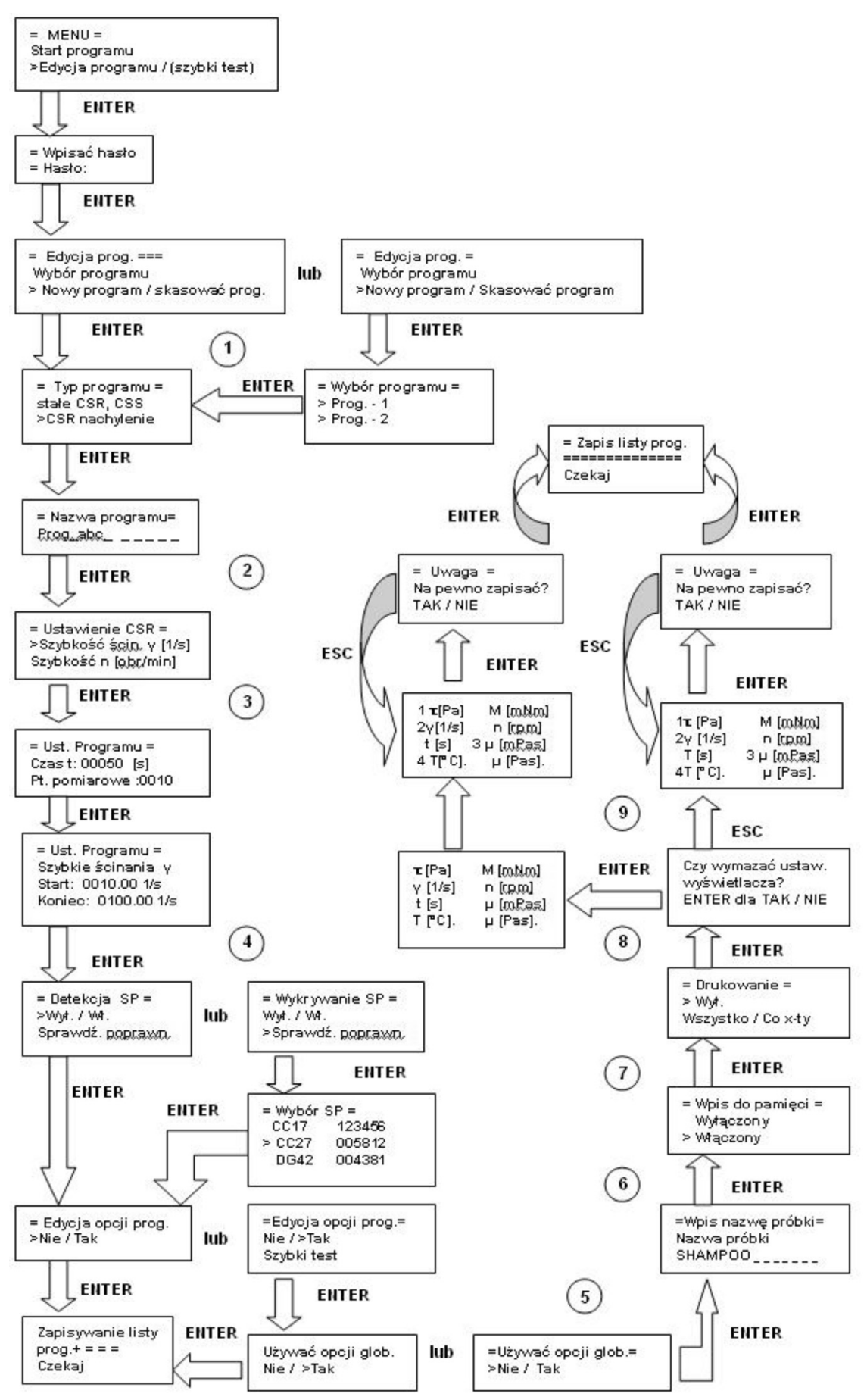

Fig. 3. The algorithmic work schematics of the rheometer ReolabQC

Rys. 3. Schemat algorytmu pracy reometru ReolabQC dalej temperaturę $\mathrm{w}$ zakresie od $-3^{\circ} \mathrm{C}$ do $-15^{\circ} \mathrm{C}$, zanotowano znaczny wzrost lepkości dynamicznej. Przy temperaturze $-5^{\circ} \mathrm{C}$ lepkość dynamiczna wynosiła ok. $20 \mathrm{mPa} \cdot \mathrm{s}$, natomiast $\mathrm{w}$ temperaturze $-15^{\circ} \mathrm{C}$ lepkość wzrosła ponad czterokrotnie i wyniosła $96 \mathrm{mPa} \cdot \mathrm{s}$

Na rysunku 4b pokazano, jaki wpływ na lepkość dynamiczną biopaliwa B100 RME wywiera siła ścinająca. Badania wykonano dla stałej temperatury wynoszącej $25^{\circ} \mathrm{C}$. Jak widać $\mathrm{z}$ rysunku, lepkość dynamiczna w tej samej temperaturze zmienia swoje wartości w zakresie od 7 do $15 \mathrm{mPa} \cdot \mathrm{s}$. Okazuje się więc, że przy dużych wzrostach szybkości ścinania wartość lepkości dynamicznej znacznie rośnie, nawet ponad dwukrotnie. Ta informacja jest szczególnie ważna przy zasilaniu silników nowej generacji, a więc z pompowtryskiwaczami lub systemami common rail, w których mamy do czynienia z bardzo wysokimi ciśnieniami wtrysku oraz dzieleniem dawki na kilka mniejszych dawek. W takich układach mamy do czynienia ze znacznymi przyrostami szybkości ścinania, dlatego lepkość dynamiczna niezależnie od temperatury może znacznie rosnąć, powodując dodatkowe zwiększeniu oporu przepływu paliwa.

Na rysunku 5a i 6a zaprezentowano wyniki badań pokazujące charakter zmian lepkości dynamicznej odpowiednio biopaliwa typu B20 i B5 (5 i 20\% RME). Dla paliwa typu B20 przy temperaturze $30^{\circ} \mathrm{C}$ lepkość wynosiła $6,5 \mathrm{mPa} \cdot \mathrm{s}$, by przy obniżeniu temperatury do $-15^{\circ} \mathrm{C}$ osiągnąć wartość $12,2 \mathrm{mPa} \cdot \mathrm{s}$. Dla paliwa typu B5 w temperaturze $30^{\circ} \mathrm{C}$ $\mathrm{mPa} \cdot \mathrm{s}$. With the increasing shearing rate the dynamic viscosity grew, reaching the value of $8.5 \mathrm{mPa} \cdot \mathrm{s}$ at $2000 \mathrm{~s}^{-1}$. The above mentioned facts show that for the same temperature the viscosity rate at the changing shearing rate may increase more than three times.

\section{Summary}

The dynamic viscosity of B100 RME biofuels in the temperature range from 30 to $-15^{\circ} \mathrm{C}$ assumes the values from c.a. 10 to $95 \mathrm{mPa} \cdot \mathrm{s}$. The dynamic viscosity changes uzyskano lepkość $6,3 \mathrm{mPa} \cdot \mathrm{s}$. Wraz z ochładzaniem próbki paliwa lepkość rosła, by przy temperaturze $-15^{\circ} \mathrm{C}$ osiągnąć wartość 9,7 $\mathrm{mPa} \cdot \mathrm{s}$.

Na rysunkach 5b, 6b pokazano, jaki wpływ na lepkość dynamiczną wywierają siły ścinające. Rysunek 4b pokazuje charakter zmian dla biopaliwa typu B20. Przy siłach ścinających bliskich zeru lepkość dynamiczna wynosiła 3,5 $\mathrm{mPa} \cdot \mathrm{s}$. Wraz ze wzrostem szybkości ścinania lepkość 


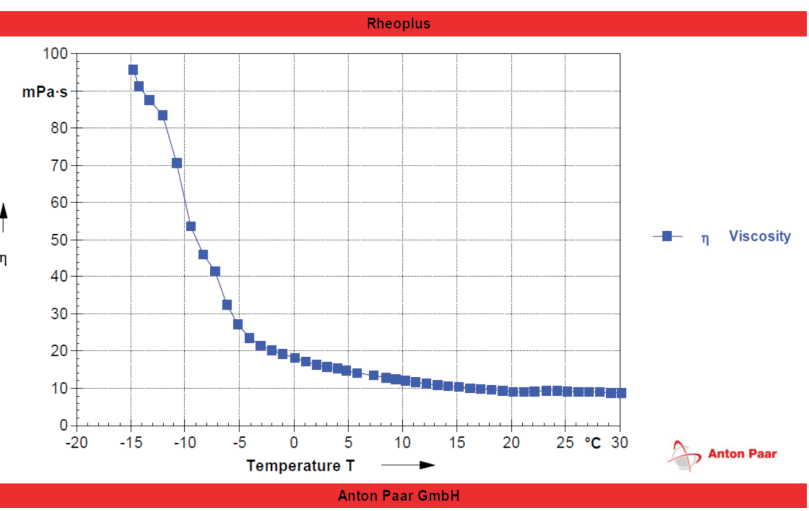

Fig. 4a. Diagram of B100 RME dynamic viscosity dependence in the function of temperature

Rys. 4a. Wykres zależności lepkości dynamicznej B100 RME jako funkcji temperatury

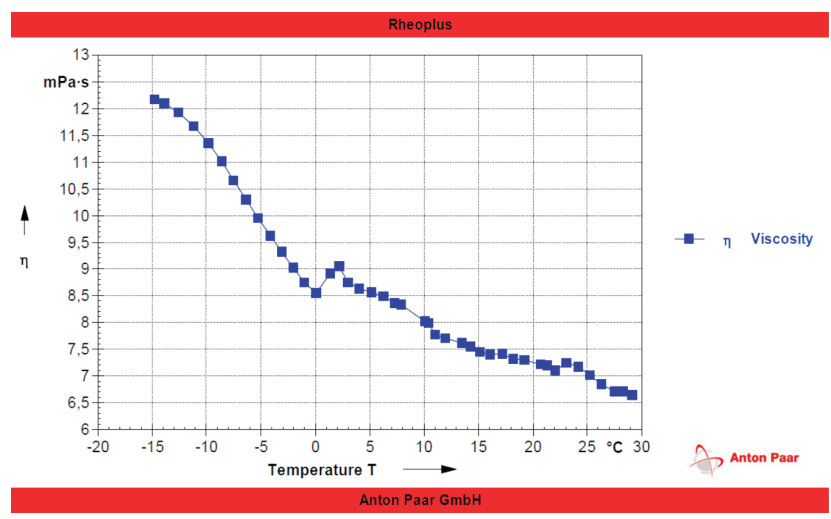

Fig. 5a. Diagram of B20 RME dynamic viscosity dependence on the temperature

Rys. 5a. Wykres zależności lepkości dynamicznej B20 RME od temperatury

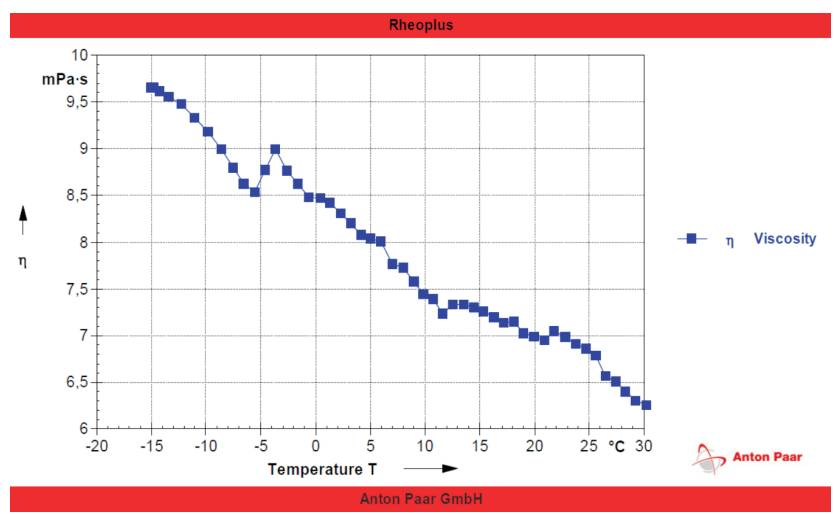

Fig. 6a. Diagram of B5 RME dynamic viscosity dependence on temperature

Rys. 6a. Diagram of B5 RME dynamic viscosity dependence on the temperature

its value not only in the function of temperature but also in the shearing rate function. At the temperature of $25^{\circ} \mathrm{C}$ the dynamic viscosity of B100RME biofuels within the shearing rate from 0 to $2000 \mathrm{~s}^{-1}$ changes its value from 7 to 15 $\mathrm{mPa} \cdot \mathrm{s}$. The dynamic viscosity of B20 RME biofuels at $30^{\circ} \mathrm{C}$ was $6.5 \mathrm{mPa} \cdot \mathrm{s}$. When the temperature decreased, the value of the dynamic viscosity increased and at $-15^{\circ} \mathrm{C}$ reached

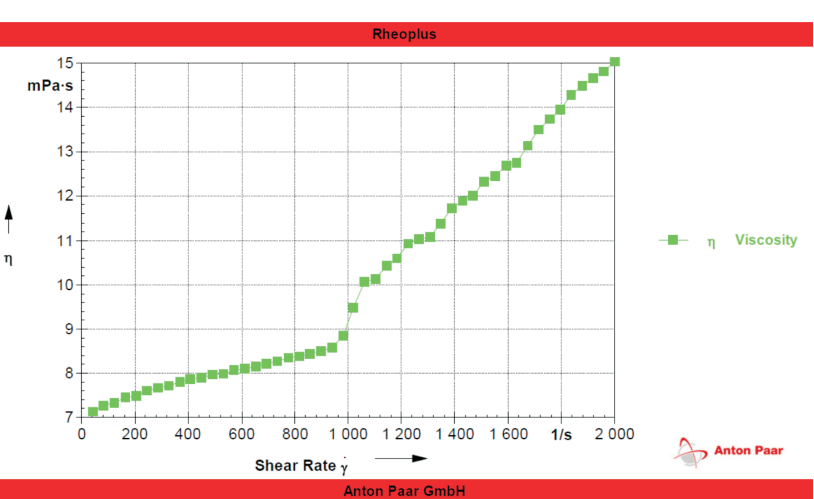

Fig. 4b. Diagram of B100 RME dynamic viscosity dependence on the shearing forces

Rys. 4b. Wykres zależności lepkości dynamicznej B100 RME od sit ścinajacych

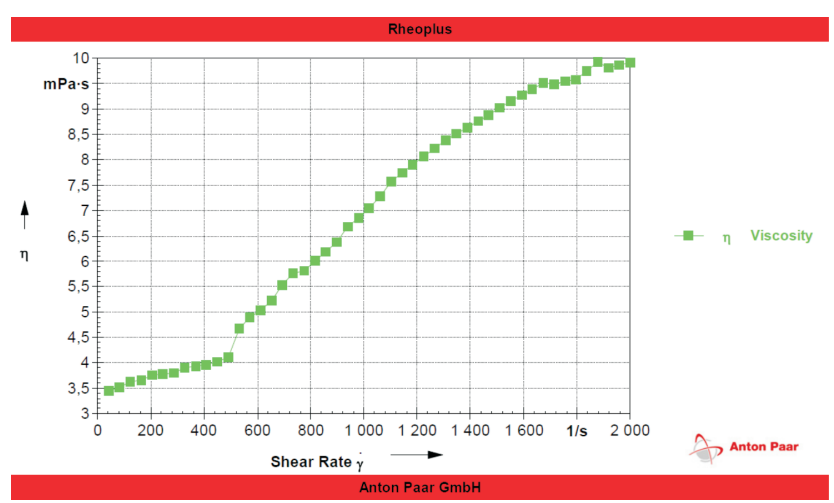

Fig. 5b. Diagram of B20 RME dynamic viscosity dependence on the shearing forces

Rys. 5b. Wykres zależności lepkości dynamicznej B20 RME od sit ścinajacych

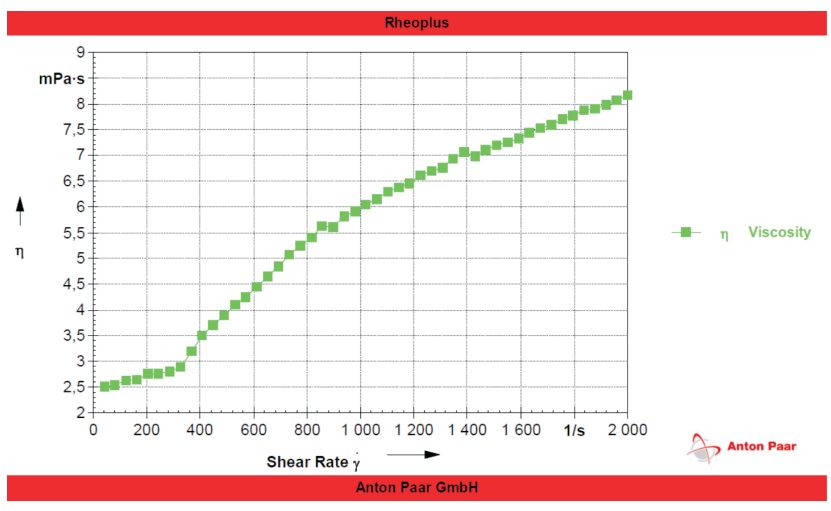

Fig. 6b. Diagram of B5 RME dynamic viscosity dependence on the shearing forces

Rys. 6b. Wykres zależności lepkości dynamicznej B5 RME od sit ścinajacych

rośnie, by przy maksymalnej wielkości tego parametru wynoszącej $2000 \mathrm{~s}^{-1}$ osiągnąć wartość $10 \mathrm{mPa}$ ·s. Jak widać, dla tej samej temperatury lepkość dynamiczna może zwiększyć swoją wartość prawie trzykrotnie. Na rysunku 5b pokazano, jak zmienia się lepkość dynamiczna biopaliwa B5 w funkcji szybkości ścinania. Dla najmniejszych wartości tego parametru lepkość dynamiczna przyjmowała 
$12.2 \mathrm{mPa} \cdot \mathrm{s}$. The dynamic viscosity for $\mathrm{B} 5$ biofuel at $30^{\circ} \mathrm{C}$ was $6.3 \mathrm{mPa} \cdot \mathrm{s}$, but with the cooling fuel sample it grew to reach $9.7 \mathrm{mPa} \cdot \mathrm{s}$ at $-15^{\circ} \mathrm{C}$. A more serious dependency of the dynamic viscosity on the shearing rate was assessed for B20 and B5RME biofuels than for B100. For the range of the shearing rate changes from 0 to $2000 \mathrm{~s}^{-1}$ the dynamic viscosity for $\mathrm{B} 20$ changed its values from 3.5 to $10 \mathrm{mPa} \cdot \mathrm{s}$ and for B5 biofuel from 2.5 to $8.5 \mathrm{mPa} \cdot \mathrm{s}$. The above mentioned values show that depending on the shearing rate, the dynamic viscosity of B20 and B5 biofuels may increase up to three times at the same temperature.

The conducted research demonstrated that the dynamic viscosity of " $\mathrm{B}$ " biofuels is considerably affected not only by the temperature, as has been hitherto assumed, but also by the shearing rate. Therefore, for a better assessment of the effect of diesel engine fuelling with biofuels on the durability and reliability of the injection systems, not the kinematic but the dynamic viscosity should be considered. It is important because the changes of the dynamic viscosity illustrate the actual changes of the flow resistance accompanying the engine fuelling with biofuels and biocomponents. The currently conducted research focuses on the introduction of a proper standard for determining the dynamic viscosity of fuels and biofuels. There are standards for rotary rheometers by means of which the dynamic viscosity and other parameters, including surface tension, shearing forces, the shearing rate or the shearing tension may be accurately determined, which will enable a better analysis of the rheological properties of fuels and biofuels.

\section{Bibliography/Literatura}

[1] Polish Standard PN-EN 590:2006. Paliwa do pojazdów samochodowych - oleje napędowe -wymagania i metody badań.

[2] Polish Standard PN-EN ISO 3104:2004. Przetwory naftowe. Ciecze przezroczyste i nieprzezroczyste. Oznaczanie lepkości kinematycznej i obliczanie lepkości dynamicznej.

[3] Szlachta Z., Zabłocki M., Cisek J. Sowa. K.: Badania wpływu paliw z oleju rzepakowego na rozruch i pracę silników wysokoprężnych w niskich temperaturach otoczenia. Badania wykonane w ramach projektu KBN nr 9 S604 013 04. Kraków 1995. Sprawozdanie IPSiSS PK, nr 490/KBN/95 (mat. niepublikowane).

[4] Cieślikowski B., Juliszewski T., Mazurkiewicz J.: Lepkość kinematyczna biopaliwa i fazy glicerynowej. Inżynieria Rolnicza, vol. 12, 2006.

[5] Szlachta Z.: Zasilanie silników wysokoprężnych paliwami rzepakowymi. WKiŁ, Warszawa 2002.

[6] Standard DIN 53019 - Układ pomiarowy reometru o cylindrach współosiowych.

[7] Wcisło G.: Wyznaczenie wpływu temperatury na lepkość dynamiczną biopaliw roślinnych. Inżynieria Rolnicza, vol. 10 (108), 2008.

[8] Juva A., Helenka P., Tritthart P.: Influence of Diesel Fuel Properties and Ambient Temperature on Engine Operation and Exhaust Emissions. SAE Transactions, vol. 89 0012, 1989. wartość 2,5 $\mathrm{mPa} \cdot \mathrm{s}$. Wraz ze wzrostem szybkości ścinania rosła lepkość dynamiczna, osiągając przy $2000 \mathrm{~s}^{-1}$ wartość $8,5 \mathrm{mPa} \cdot \mathrm{s}$. Z powyższego wynika, że dla tej samej temperatury lepkość dynamiczna przy zmieniającej się szybkości ścinania może wzrastać ponad trzykrotnie.

\section{Podsumowanie}

Lepkość dynamiczna biopaliwa B100 RME w zakresie temperatur od 30 do $-15^{\circ} \mathrm{C}$ przyjmuje wartości od ok. 10 do $95 \mathrm{mPa} \cdot \mathrm{s}$. Lepkość dynamiczna zmienia swoją wartość nie tylko w funkcji temperatury, ale również w funkcji szybkości ścinania. Przy temperaturze $25^{\circ} \mathrm{C}$ lepkość dynamiczna biopaliwa B100 RME w zakresie szybkości ścinania od 0 do $2000 \mathrm{~s}^{-1}$ zmieniła swoją wartość od 7 do $15 \mathrm{mPa} \cdot \mathrm{s}$. Lepkość dynamiczna biopaliwa typu B20 w temperaturze $30^{\circ} \mathrm{C}$ wynosiła $6,5 \mathrm{mPa} \cdot \mathrm{s}$. Przy obniżaniu temperatury, jej wartość rosła $\mathrm{i} \mathrm{w}$ temperaturze $-15^{\circ} \mathrm{C}$ osiągnęła $12,2 \mathrm{mPa} \cdot \mathrm{s}$. Dla paliwa typu $\mathrm{B} 5 \mathrm{w}$ temperaturze $30^{\circ} \mathrm{C}$ lepkość dynamiczna wynosiła $6,3 \mathrm{mPa} \cdot \mathrm{s}$. Wraz z ochładzaniem próbki paliwa lepkość rosła, by w temperaturze $-15^{\circ} \mathrm{C}$ osiągnacé wartość 9,7 mPa·s. Dla biopaliw B20 i B5 RME stwierdzono większą zależność lepkości dynamicznej od szybkości ścinania niż dla B100. Dla zakresu zmian szybkości ścinania od 0 do $2000 \mathrm{~s}^{-1}$ lepkość dynamiczna dla B20 zmieniała wartość od 3,5 do $10 \mathrm{mPa} \cdot \mathrm{s}$, dla biopaliwa B5 od 2,5 do 8,5 $\mathrm{mPa} \cdot \mathrm{s}$. $\mathrm{Z}$ powyższego widać, że dla tej samej temperatury lepkość dynamiczna biopaliw B20 i B5 w zależności od szybkości ścinania może wzrosnąć nawet trzykrotnie.

Przeprowadzone badania wykazały, że na lepkość dynamiczną biopaliw B duży wpływ wywiera nie tylko temperatura, jak dotychczas sądzono, ale również szybkość ścinania. W związku z tym dla lepszej oceny wpływu zasilania silników ZS biopaliwami na trwałość i niezawodność aparatury wtryskowej, należy uwzględniać nie lepkość kinematyczną, lecz dynamiczną. Dlatego, że to zmiany lepkości dynamicznej mówią o faktycznych zmianach oporów przepływów towarzyszących zasilaniu silników biopaliwami i biokomponentami. Obecnie są prowadzone prace nad wprowadzeniem stosownej normy dotyczącej bezpośredniego wyznaczania lepkości dynamicznej paliw i biopaliw. Istnieją normy dotyczące reometrów rotacyjnych, za pomocą których można $\mathrm{z}$ bardzo dużą dokładnością wyznaczać lepkość dynamiczną oraz inne parametry, takie jak: napięcie powierzchniowe, siły ścinające, szybkość ścinania, napięcie ścinania, które pozwolą na szerszą analizę właściwości reologicznych paliw i biopaliw.

Artykut recenzowany

Mr. Grzegorz Wcisło, DEng. - doctor in the Faculty of Production Engineering and Power Technologies, Agricultural University of Cracow.

Dr inż. Grzegorz Wcisto - adiunkt na Wydziale Inżynierii Produkcji i Energetyki Uniwersytetu Rolniczego w Krakowie.

e-mail: grzegorz.wcislo@ur.krakow.pl 